\title{
PROMOSI MAKANAN SEHAT DAN BERGIZI DALAM UPAYA PENINGKATAN STATUS GIZI IBU HAMIL
}

\section{HEALTHY AND NUTRITIOUS FOOD PROMOTION IN AN ATTEMPT INCREASING NUTRITION STATUS OF PREGNANT WOMEN}

\author{
Azrimaidaliza $^{1)}$, Rozaliny Asri ${ }^{2)}$, Meta Handesti ${ }^{3)}$, Yossi Lisnayenti ${ }^{4)}$ \\ ${ }^{1)}$ Fakultas Kesehatan Masyarakat, Universitas Andalas, email: azrimaidaliza75@gmail.com \\ ${ }^{2)}$ Fakultas Kesehatan Masyarakat, Universitas Andalas, email: asrirozaliny@gmail.com \\ ${ }^{3)}$ Fakultas Kesehatan Masyarakat, Universitas Andalas, email: metahandesti91@yahoo.com \\ ${ }^{4)}$ Fakultas Kesehatan Masyarakat, Universitas Andalas, email: yossilisnayenti@gmail.com
}

\begin{abstract}
ABSTRAK
Ibu hamil termasuk dalam kelompok rentan gizi. Kebutuhan gizi yang tidak terpenuhi pada masa kehamilan mempengaruhi kondisi gizi ibu dan tumbuh kembang janin, berikutnya bisa mempengaruhi kondisi bayi yang dilahirkan, yaitu berupa berat lahir rendah, panjang lahir pendek dan pertumbuhan otak tidak optimal. Tujuan jangka panjang kegiatan pengabdian yaitu untuk membantu mengatasi permasalahan gizi pada ibu hamil dan jangka pendek yaitu meningkatkan pengetahuan ibu hamil, kemudian meningkatkan sikap positif dan perilaku makan yang sehat dan bergizi selama kehamilan sehingga memberikan dampak positif bagi status gizi bayi yang dilahirkan. Sasaran kegiatan adalah ibu hamil yang mengikuti kelas ibu hamil yang diselenggarakan oleh Puskesmas Lapai. Kegiatan pengabdian berupa Komunikasi Informasi dan Edukasi (KIE), meliputi kegiatan pre-test, penyampaian materi disertai pemberian leafleat dan kegiatan post-test. Hasil kegiatan menunjukkan peningkatan pengetahuan gizi ibu hamil berdasarkan hasil pre-test dan post-test. Tingkat pengetahuan ibu hamil dengan kategori baik saat pre-test adalah sebanyak 3 orang, sedangkan pada saat posttest meningkat menjadi 11 orang $(91.7 \%)$. Kegiatan berjalan dengan lancar dan ibu hamil memahami konsep tentang gizi ibu hamil. Kegiatan ini diharapkan dapat dilaksanakan secara rutin dengan adanya kerjasama antara institusi kesehatan dan pendidikan di semua Puskesmas di Kota Padang, selain jumlah peserta yang ikut berpartisipasi lebih banyak.
\end{abstract}

Kata Kunci : Promosi kesehatan, Tingkat pengetahuan, Ibu hamil

\section{ABSTRACT}

Pregnant women are vulnerable nutrition groups. Unmet maternal nutritional needs during pregnancy affect the mother's nutritional condition and fetal growth, the next can affect the condition of the babies born, namely low birth weight, short birth length and brain growth is not optimal. The long-term goal is to help overcome the nutritional problems in pregnant women and the short-term goal is to increase the knowledge of pregnant women so that they have good nutritional status and health, and have a good impact for the babies born. The target is pregnant women who attend pregnant mothers classes in Lapai Health Center. This program is Communication Information and Education in the form of Pre-test, the presentation about good nutritional status and nutritious healthy diet during pregnancy accompanied by giving leaflets, and Post-test. The results showed that there was a significant increase in pregnant mother's nutritional knowledge by doing Pre-test and Post-test. The knowledge level of pregnant women with good category when the Pre-test are 3 people when Post-test increased to 11 people (91.7\%). Activities run smoothly and pregnant women have understood the concept of pregnant women's nutrition. Hopefully, this activity is routinely carried out and the total of pregnant women's participation increases.

Keywords: Health Promotion, Knowledge Level, Pregnant women 


\section{PENDAHULUAN}

Ibu hamil termasuk dalam kelompok rentan gizi. Kebutuhan gizi ibu yang tidak terpenuhi pada masa kehamilan akan mempengaruhi kondisi gizi ibu dan tumbuh kembang janin, kemudian bisa mempengaruhi kondisi gizi dan kesehatan bayi yang dilahirkan, antara lain berat bayi yang dilahirkan rendah, panjang lahir pendek dan pertumbuhan otak tidak optimal (Ramachandran, 2011; Thangaratinam, et al, 2012). Beberapa studi sudah membuktikan mengenai dampak bahwa bayi dengan panjang lahir pendek berisiko mengalami pertumbuhan stunting pada usia berikutnya (Anugraheni, 2012 dan Ernawati, 2013) sedangkan bayi dengan berat lahir rendah salah satunya berisiko mengalami penyakit degeneratif pada usia dewasa.

Hasil Riset Kesehatan Dasar atau disingkat Riskesdas tahun 2007, 2010 dan 2013 melaporkan prevalensi bayi dengan berat badan lahir rendah atau disingkat BBLR di Sumatera Barat pada tahun 2007 $(8,0 \%)$ mengalami sedikit penurunan tahun 2010 (6,0\%), kemudian tahun 2013, prevalensinya kembali meningkat $(8,0 \%)$. Pada tahun 2013, juga diketahui prevalensi bayi dengan panjang lahir pendek (panjang badan $<48 \mathrm{~cm}$ ) di Sumatera Barat sebesar $15,5 \%$. Selain itu diperoleh informasi kejadian Kurang Energi Kronis (KEK) tahun 2013 pada wanita hamil 15-49 tahun di Propinsi Sumatera sebesar 19\% kemudian prevalensi wanita hamil berisiko tinggi $(\mathrm{TB}<150 \mathrm{~cm})$ yaitu sebesar $38 \%$.

Hasil penelitian Azrimaidaliza di Puskesmas dalam wilayah kerja Dinas Kesehatan Kota Padang tahun 2015 diperoleh kejadian BBLR di Kota Padang sebesar 3,5\%, bayi dengan berat badan kurang dari 3000 gram sebesar $41,3 \%$ dan kejadian bayi dengan panjang lahir pendek $(<48 \mathrm{~cm})$ sebesar 28,9\%. Hasil penelitian ini juga menemukan bahwa asupan energi ibu hamil belum memenuhi 80\% Angka Kecukupan Gizi (AKG) yang dianjurkan tahun 2013 atau masih dibawah dari yang dianjurkan dengan rata-rata asupan energi sebesar yaitu 1831,1 kkal dengan standar devaisi 222,5 kkal pada ibu hamil umur 20 sampai dengan 35 tahun dan ibu hamil umur diatas 35 tahun sebesar 1855,5 kkal dengan standar deviasi 209,5 kkal.

Salah satu faktor yang mempengaruhi terjadinya BBLR adalah kurangnya pengetahuan ibu hamil terkait makanan bergizi dan status gizi ibu selama kehamilan. Pengetahuan ibu akan meningkat salah satunya dengan diberikan penyuluhan kesehatan, Penyuluhan kesehatan adalah kegiatan pendidikan yang dilakukan dengan cara menyebarkan pesan, menanamkan keyakinan, sehingga masyarakat tidak saja sadar, tahu atau mengerti, tetapi juga mau dan bisa melakukan sesuatu anjuran yang ada hubungannya dengan kesehatan. (Maulana, 2009) 
Pentingnya Pengetahuan atau kognitif merupakan faktor domain yang sangat penting untuk terbentuknya tindakan seseorang (Over Behavior), dari pengalaman dan penelitian ternyata perilaku yang didasari oleh pengetahuan akan lebih langgeng dari pada perilaku yang tidak didasari oleh pengetahuan, sebelum orang mengadopsi perilaku baru (berperilaku baru) didalam diri seseorang. Penyuluhan merupakan salah satu faktor yang meningkatkan pengatahuan masyarakat yang berakibat tahu dan mampu menjalankan perilaku konsumsi makanan sehat dan bergizi, sehingga perlu di berikan informasi melalui penyuluhan promosi makanan sehat dan bergizi. (Notoatmodjo, 2007)

Puskesmas Lapai merupakan salah satu Puskesmas yang ada dalam wilayah kerja Dinas Kesehatan Kota Padang yang berlokasi di Jalan Joni Anwar Lapai I Perumnas, Kecamatan Nanggalo. Puskesmas ini termasuk dalam kelompok Puskesmas non perawatan yang terletak di Pusat Kota Padang.

Data Profil Kesehatan Kota Padang Tahun 2012 menunjukkan bahwa persentase kejadian bayi yang lahir dengan berat badan rendah atau disingkat BBLR adalah kecil, sekitar 0,8\%. Namun persentase balita dengan status gizi kurang cukup tinggi yaitu sebesar $10,83 \%$ dan balita dengan status gizi buruk, yaitu sebesar 5,0\%. Gambaran mengenai angka kunjungan ibu hamil ke
Puskesmas Lapai sebagai berikut; K1 sebesar 97,4\% dan K4 sebesar 89,3\%.

\section{METODE PELAKSANAAN KEGIATAN}

Kegiatan pengabdian kepada masyarakat dilaksanakan berupa kegiatan Komunikasi Informasi dan Edukasi (KIE) dengan tahapan sebagai berikut;

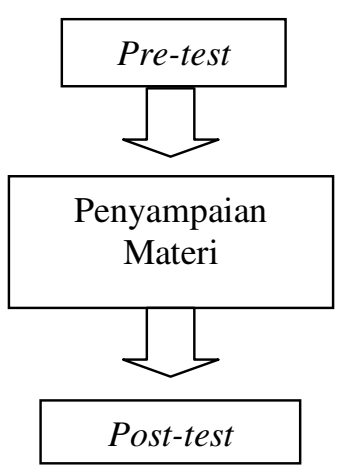

Gambar 1.Tahapan Kegiatan Pengabdian kepada Masyarakat

Kegiatan pengabdian kepada masyarakat dilaksanakan bersamaan dengan kegiatan Kelas Ibu Hamil di Puskesmas Lapai yang terdapat dalam Wilayah Kerja Dinas Kesehatan Kota Padang. Pengabdian ini dilaksanakan 1 kali dalam kegiatan Kelas Ibu Hamil sehingga diharapkan ibu dapat memahami materi yang disampaikan kemudian materi yang kurang dipahami dapat ditanyakan pada pertemuan selanjutnya.

Kegiatan pengabdian kepada masyarakat dilaksanakan dengan mempersiapkan materi penyuluhan, antara lain; (1) pengertian ibu hamil, (2) status gizi, (3) Hal-hal yang perlu diperhatikan selama kehamilan (4) pola makanan sehat dan bergizi selama kehamilan. 


\section{HASIL DAN PEMBAHASAN}

Puskesmas Lapai berlokasi di Kecamatan Nanggalo dengan wilayah kerja sebanyak 3 (tiga) kelurahan, yaitu: (1) Kelurahan Kampung Lapai, (2) Kelurahan Kampung Olo, dan (3) Kelurahan Tabing Banda Gadang.

Luas wilayah kerja Puskesmas Lapai (3 kelurahan) lebih kurang $2.000 \mathrm{~km}^{2}$ dengan batas-batasnya sebagai berikut;

a. Sebelah Utara dengan Kelurahan Kurao Pagang dan Kelurahan dan Kelurahan Surau Gadang Kecamatan Nanggalo.

b. Sebelah Selatan dengan Kecamatan Padang Utara.

c. Sebelah Timur dengan Kelurahan Gurun Lawas dan Kelurahan Surau Gadang Kecamatan Nanggalo.

d. Sebelah Barat dengan Kecamatan Padang Utara.

Pada umumnya wilayah kerja Puskesmas Lapai telah dapat dijangkau oleh transportasi kendaraan roda dua maupun roda empat, kecuali ada beberapa daerah di Kelurahan Tabing Banda Gadang yang hanya bisa dilalui oleh kendaraan roda dua.

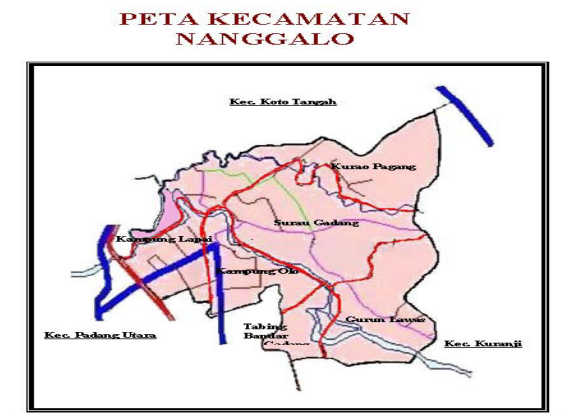

Gambar 2. Peta Kecamatan Nanggalo Kota Padang
Kegiatan pengabdian kepada masyarakat berupa "Promosi Makanan Sehat dan Bergizi dalam Upaya Peningkatan Status Gizi Ibu Hamil di Puskesmas Lapai Padang" dilaksanakan pada Hari Sabtu, tanggal 12 November 2016 yang berlokasi di Balai Pemuda Lapai. Kegiatan yang dilakukan, sebagai berikut ;

1. Persiapan sebelum kegiatan, meliputi;

a. Pengurusan izin untuk kegiatan pengabdian kepada masyarakat ke Dinas Kesehatan Kota Padang dan Puskesmas Lapai Padang.

b. Pembuatan leafleat tentang gizi ibu hamil.

c. Penyusunan kuesioner pre-test dan post-test untuk mengetahui tingkat pengetahuan gizi ibu hamil. Pertanyaan yang diajukan disusun sebanyak 10 buah.

d. Pembuatan spanduk untuk kegiatan.

e. Koordinasi dengan Tenaga Kesehatan di Puskesmas Lapai untuk mengumpulkan ibu hamil yang ikut kegiatan.

f. Pembuatan materi untuk kegiatan promosi gizi.

2. Pelaksanaan kegiatan promosi "Makanan Sehat dan Bergizi dalam Upaya Peningkatan Status Gizi Ibu Hamil di Puskesmas Lapai Padang" sebagai berikut; a. Kegiatan diikuti oleh; 12 ibu hamil, 4 kader dan 4 tenaga kesehatan di Puskesmas Lapai. 
b. Kegiatan diawali dengan penjelasan kepada Ibu Hamil mengenai kegiatan pengabdian dan kepesertaan ibu hamil dalam BPJS. Hal ini disampaikan oleh Penanggung Jawab Program Kesehatan Ibu Anak Puskesmas Lapai.

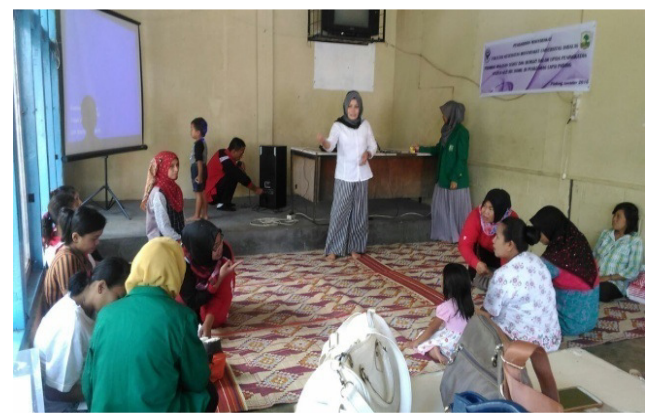

Gambar 3. Penjelasan kegiatan Pengabdian dan Kepesertaan Ibu hamil dalam BPJS

c. Kegiatan pre-test dilakukan sebelum disampaikannya materi tentang "Makanan Sehat dan Bergizi dalam Upaya Peningkatan Status Gizi Ibu Hamil". Ibu hamil diminta untuk menjawab beberapa pertanyaan (kuesioner) yang terkait dengan materi yang akan disampaikan.

d. Penyampaian materi oleh Pengabdi dengan menggunakan metoda ceramah menggunakan komputer dan LCD kemudian setelah penyampaian materi, ibu hamil diberi kesempatan untuk mengajukan pertanyaan. Ibu hamil yang hadir dalam kegiatan ini cukup antusias dan semangat dengan materi yang disampaikan. Hal ini terlihat dari pertanyaan-pertanyaan yang diajukan.

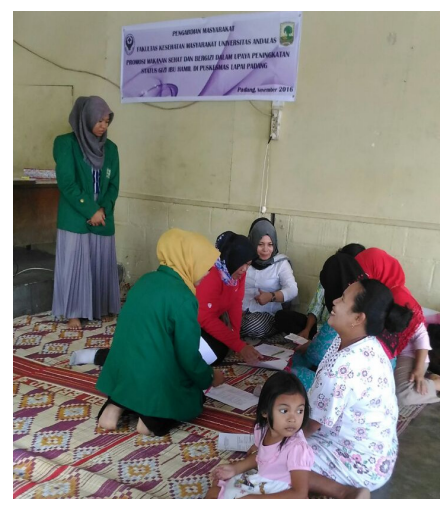

Gambar 4. Kegiatan Pre-test sebelum penyampaian materi penyuluhan

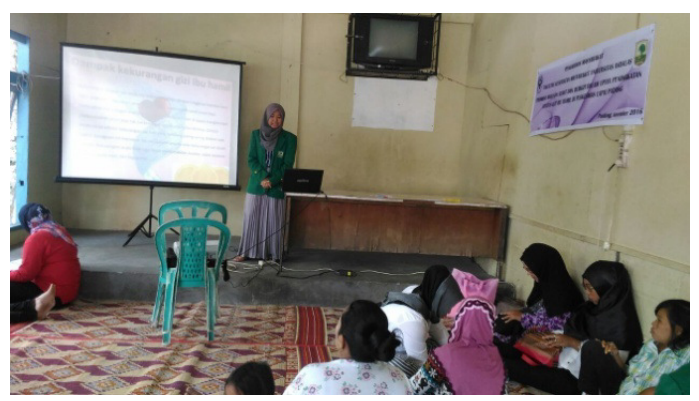

Gambar 5. Penyampaian materi oleh pengabdi

Berdasarkan hasil kegiatan pengadian diperoleh gambaran karakteristik ibu hamil, yaitu tingkat pendidikan ibu yang ikut kegiatan pengabdian dapat dilihat pada tabel dan grafik berikut ;

Tabel 1. Distribusi Frekuensi Karakteristik Responden Menurut Pendidikan

\begin{tabular}{lll}
\hline \multirow{2}{*}{ Pendidikan } & \multicolumn{2}{l}{ Jumlah } \\
\cline { 2 - 3 } & $\mathbf{f}$ & $\mathbf{\%}$ \\
\hline Tidak Sekolah & 1 & 8.3 \\
SMP & 2 & 16.7 \\
SMA & 5 & 41.7 \\
SMK & 1 & 8.3 \\
Perguruan & 3 & 25.0 \\
Tinggi & & \\
Jumlah & $\mathbf{1 2}$ & $\mathbf{1 0 0 , 0}$ \\
\hline
\end{tabular}


Pada Tabel 1 dapat dijelaskan bahwa tingkat pendidikan ibu hamil yang paling banyak adalah SMA yaitu sebanyak 5 orang $(41.7 \%)$.

Tabel 2. Distribusi Frekuensi Karakteristik Responden Menurut Usia Kehamilan

\begin{tabular}{lll}
\hline Usia & \multicolumn{2}{l}{ Jumlah } \\
\cline { 2 - 3 } Kehamilan & $\mathbf{f}$ & $\mathbf{\%}$ \\
\hline Trimester 1 & 0 & 0 \\
Trimester 2 & 4 & 33.3 \\
Trimester 3 & 8 & 66.7 \\
Jumlah & $\mathbf{1 2}$ & $\mathbf{1 0 0 , 0}$
\end{tabular}

Karakteristik ibu hamil menurut usia kehamilan dapat dijelaskan bahwa ibu hamil yang mengikuti kegiatan kelas ibu hamil paling banyak presentasenya adalah ibu hamil dengan usia kehamilan trimester 3 (7-9 bulan) yaitu sebanyak 8 orang (66.7\%). Secara umum, status gizi ibu hamil melalui observasi yang dilakukan menunjukkan bahwa status gizi ibu hamil terlihat normal dan keadaan fisik ibu sehat.

Tabel 3. Distribusi Frekuensi Karakteristik Responden Menurut Jumlah Anak

\begin{tabular}{lll}
\hline \multirow{2}{*}{ Jumlah anak } & \multicolumn{2}{l}{ Jumlah } \\
\cline { 2 - 3 } & $\mathbf{F}$ & $\mathbf{\%}$ \\
\hline Tidak ada & 1 & 8.3 \\
1 orang & 5 & 41.7 \\
2 orang & 6 & 50.0 \\
Jumlah & $\mathbf{1 2}$ & $\mathbf{1 0 0 , 0}$
\end{tabular}

Berdasarkan Tabel 3 dapat diketahui bahwa ibu hamil memiliki paling banyak 2 orang anak yaitu sebanyak 6 orang responden $(50.0 \%)$. e. Kegiatan pengabdian kepada ibu hamil ditutup dengan kegiatan post test, yaitu ibu hamil diminta untuk menjawab pertanyaan-pertanyaan dalam kuesioner mengenai gizi pada ibu hamil. Pertanyaan tersebut sama dengan pertanyaan yang disampaikan pada kegiatan pre-test.

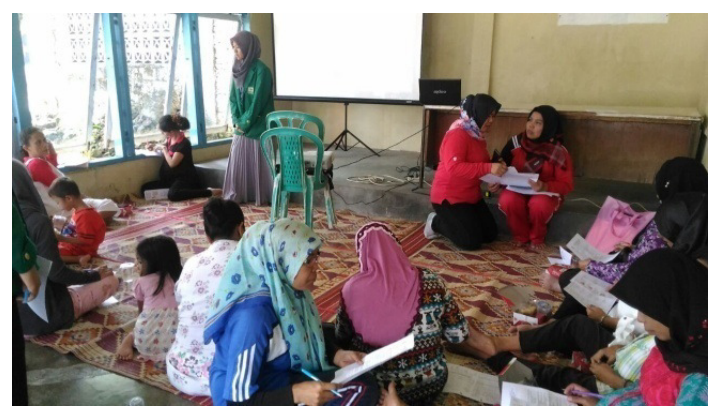

Gambar 6. Kegiatan Post-test setelah penyampaian materi penyuluhan

Pengetahuan gizi ibu hamil dikelompokkan menjadi 2 kategori, yaitu pengetahuan gizi baik dan pengetahuan gizi kurang. Pengetahuan gizi baik apabila ibu hamil dapat menjawab pertanyaan betul sebanyak $\geq 8$ pertanyaan dari 10 pertanyaan dan pengetahuan gizi kurang apabila ibu dapat menjawab pertanyaan betul sebanyak < 8 pertanyaan dari 10 pertanyaan.

Hasil kegiatan pre-test dan post-test menunjukkan gambaran tingkat pengetahuan gizi ibu hamil, dengan hasil sebagai berikut; 


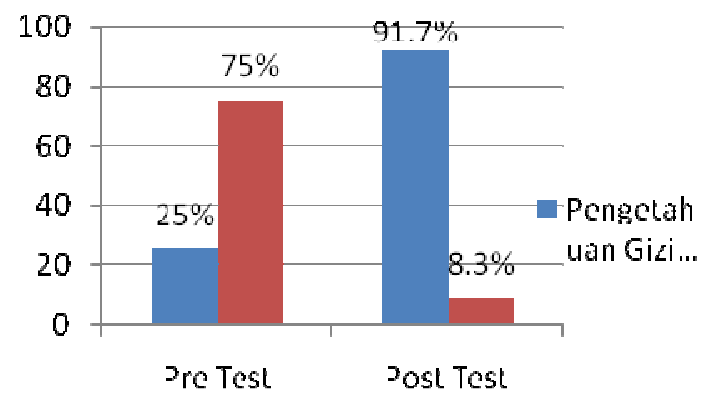

Grafik 1. Tingkat Pengetahuan Gizi Ibu Hamil berdasarkan kegiatan Pre-test dan Post-test pada Kelas Ibu Hamil Puskesmas Lapai Padang Tahun 2016

Berdasarkan grafik 1 dapat diinformasikan bahwa terdapat peningkatan pengetahuan gizi ibu hamil yang signifikan dengan melakukan kegiatan Pre-test dan Post-test. Tingkat pengetahuan ibu hamil dengan kategori baik saat Pre-test adalah sebanyak 3 orang, sedangkan pada saat Posttest meningkat menjadi 11 orang ibu hamil (91.7\%) yang memiliki tingkat pengetahuan baik.

Pengetahuan gizi ibu yang baik diharapkan dapat meningkatkan perilaku gizi yang baik juga selama kehamilan. Ibu hamil diharapkan dapat meningkatkan asupan makanan yang sehat dan bergizi sehingga status gizi ibu selama kehamilan baik dan seterusnya dapat melahirkan bayi dengan berat dan panjang lahir yang normal. Berbagai teori dan penelitian sudah membuktikan bahwa pengetahuan ibu yang kurang baik adalah salah satu faktor yang dapat menimbulkan permasalahan gizi pada ibu hamil maupun terhadap janin yang dikandungnya.
Kegiatan pengabdian kepada masyarakat seperti yang dilakukan oleh pengabdi melalui kerjasama antara institusi pendidikan dengan institusi kesehatan, salah satunya dengan Puskesmas merupakan salah satu upaya yang dapat dilakukan untuk meningkatkan pengetahuan masyarakat, khususnya mengenai pengetahuan gizi pada kelompok ibu hamil. Pemahaman tentang gizi seimbang melalui kegiatan promosi gizi diharapkan lebih efektif dan lestari sehingga meningkatkan Pengetahuan, Sikap dan Perilaku (PSP) tentang gizi seimbang ibu hamil yang selanjutnya akan meningkatkan status gizi ibu hamil dan status gizi janin yang dikandungnya.

Kegiatan pengabdian ini berupa promosi gizi pada awalnya direncanakan sebanyak 2 kali dengan tujuan agar dapat memberikan pemahaman yang lebih baik kepada ibu hamil dan harapannya mencakup sasaran yang lebih luas dan lebih banyak. Namun kesulitan yang dihadapi adalah dalam mencari waktu yang tepat dalam mengadakan kegiatan karena kegiatan ini melibatkan tenaga kesehatan di Puskesmas Lapai yang memiliki kesibukan yang sedang menghadapi proses akreditasi dan adanya program yang tiba-tiba harus dikerjakan oleh Puskesmas, yaitu mengatasi kejadian Filariasis yang mulai bermunculan kasusnya di Kota Padang. Kemudian di satu sisi mengumpulkan sejumlah ibu hamil merupakan tantangan tersendiri bagi pengabdi dan tenaga kesehatan. 


\section{KESIMPULAN}

1. Kegiatan pengabdian kepada masyarakat yang dilaksanakan di kelas ibu hamil Puskesmas Lapai berjalan dengan lancar sesuai dengan yang direncanakan.

2. Kegiatan ini terdiri dari beberapa tahapan yaitu Pre-Test, Penyuluhan atau penyampaian materi terkait status gizi ibu hamil, dan Post-test.

3. Ibu hamil antusias dengan kegiatan yang dilaksanakan dibuktikan dengan kehadiran ibu hamil dan keseriusan ibu hamil dalam mendengarkan materi yang disampaikan. Ibu hamil juga memberikan beberapa pertanyaan terkait materi yang disampaikan dan keluhan kehamilan yang dialaminya.

4. Hasil kegiatan yang sudah dilakukan menggambarkan bahwa adanya peningkatan pengetahuan dan informasi ibu hamil tentang status gizi, yang diharapakan ibu hamil memiliki status gizi dan status kesehatan yang baik, yang selanjutnya memberikan dampak yang baik bagi bayi yang nantinya akan dilahirkan.

\section{REFERENSI}

[1] Atmawikarta, Arum. 2007. Strategi Penanggulangan Masalah Gizi Melalui Desa Siaga. Disampaikan pada Pertemuan Pembahasan Penanggulangan Masalah Gizi di Propinsi Jawa Timur, Surabaya, 24 Januari 2007.

[2] Ernawati, Fitrah, Rosmalina, Yuniar dan Permanasari, Yurista. 2013. Pengaruh Asupan Protein Ibu Hamil dan Panjang Badan Bayi Lahir terhadap Kejadian
Stunting pada Anak Usia 12 bulan di Kabupaten Bogor. Jurnal Penelitian Gizi dan Makanan, Juni 2013 Vol.36 (1): 111

[3] Depkes RI. 2008. Riset Kesehatan Dasar Tahun 2007. Jakarta: Badan Penelitian dan Pengembangan Kesehatan Depkes RI.

[4] Depkes RI. 2010. Riset Kesehatan Dasar Tahun 2010. Jakarta: Badan Penelitian dan Pengembangan Kesehatan Depkes RI.

[5] DKK Padang. 2012. Profil Kesehatan Kota Padang Tahun 2012 Edisi 2013. Padang: DKK Padang.

[6] Heri D.J. Maulana. 2009. Promosi Kesehatan. Jakarta : EGC.

[7] Jus'at, Idrus, dkk. 2010. Program Sibermas Multisenter Untuk Pemberdayaan Masyarakat Sekolah Dasar di Kabupaten Tangerang, Propinsi Banten, Laporan Program Sinegi Pemberdayaan Potensi. Tangerang.

[8] Notoatmodjo S. 2007. Promosi Kesehatan dan Ilmu Perilaku. Jakarta : PT Rineka Cipta.

[9] Ramachandran, Prema. 2011. Dual Nutrition Burden in Women: Causes, Consequences and Control Measures dalam Vir, Sheila Chander. Editor. Public Health Nutrition in Developing Countries. Woodhead Publishing India PVT LTD. India.

[10] Thangaratinam, S, et al. 2012. Effects of Interventions in Pregnancy on Maternal Weight and Obstetric Outcomes: Metaanalysis of Randomised Evidence. BMJ. 344. E2088. 1-15. Diakses pada http://www.bmj.com/content/344/bmj.e 2088.pdf\%2Bhtml. 